\title{
POTENTIAL APPLICATIONS OF SOS-GFP BIOSENSOR TO IN VITRO RAPID SCREENING OF CYTOTOXIC AND GENOTOXIC EFFECT OF ANTICANCER AND ANTIDIABETIC PHARMACIST RESIDUES IN SURFACE WATER
}

\author{
Marzena Matejczyk', Stanisław Józef Rosochacki \\ 1 Department of Sanitary Biology and Biotechnology, Faculty of Civil Engineering and Environmental Enginee- \\ ring, Bialystok University of Technology, Wiejska 45E, 15-351 Bialystok, Poland, e-mail: m.matejczyk@pb.edu.pl
}

Received: 2014.08.28

Accepted: 2014.10.17

Published: 2015.01.02

\begin{abstract}
Escherichia coli K-12 GFP-based bacterial biosensors allowed the detection of cytotoxic and genotoxic effect of anticancer drug- cyclophosphamide and antidiabetic drug - metformin in PBS buffer and surface water. Experimental data indicated that recA::gfpmut2 genetic system was sensitive to drugs and drugs mixture applied in experiment. RecA promoter was a good bioindicator in cytotoxic and genotoxic effect screening of cyclophosphamide, metformin and the mixture of the both drugs in PBS buffer and surface water. The results indicated that $E$. coli $\mathrm{K}-12$ recA $: \because g f p$ mut 2 strain could be potentially useful for first-step screening of cytotoxic and genotoxic effect of anticancer and antidiabetic pharmacist residues in water. Next steps in research will include more experimental analysis to validate recA::gfpmut2 genetic system in $E$. coli K-12 on different anticancer drugs.
\end{abstract}

Keywords: SOS-gfp biosensor, cytotoxicity, genotoxicity, cyclophosphamide, metformin.

\section{INTRODUCTION}

Cyclophosphamide, ifosfamide, methotrexate, 5-fluorouracil, taxol, vinca alkaloids and platinum compounds are commonly used as chemotherapeutic agents on cancer. Cytostatic compounds have a generally polar structure and have been detected in hospital wastewaters, the influents and effluents of WWTPs and surface waters [Besse et al. 2012, Zhang et al. 2013, Yu-Chen Lin et al. 2014]. According to a review by Kosjek and Heath [Kosjek and Heath 2011], last studies have been primarily focused on hospital effluents, and only a few of them have focused on environmental samples and their fate. Most cytostatic compounds are not likely to undergo biodegradation or volatilization processes, and a limited number of studies has reported their degradation by sunlight photolysis [Kosjek and Heath 2011].

Cyclophosphamide (CP) - a cytotoxic agent that alkylates DNA, has a wide spectrum of clinical uses in the chemotherapy treatment of many neoplastic diseases. The acute toxicities of $\mathrm{CP}$ are associated with its genotoxicity. $\mathrm{CP}$ was detected worldwide at $\mathrm{ng} / \mathrm{l}$ to $\mu \mathrm{g} / \mathrm{l}$ levels in surface water $(<30-64,8 \mathrm{ng} / \mathrm{l})$ [Kosjek and Heath 2011, Besse et al. 2012, Zhang et al. 2013, Yu-Chen Lin et al. 2014].

The antidiabetic drug metformin is among the pharmaceuticals with the highest production amounts world-wide. Measurements performed in sewage and surface waters, showed an almost ubiquitous presence of metformin in the aquatic environment. Metformin was found in all investigated river waters. Concentration levels depend on the sewage fraction of the analyzed waters and in most rivers they are in the range of several to 100 $\mathrm{ng} / \mathrm{l}$, i.e. in the same order of magnitude or even higher than for other relevant pharmaceutical residues [Scheurer et al. 2009, Quinn et al. 2013].

The pharmaceutical residues of cyclophosphamide and metformin were detected worldwide at $\mathrm{ng} / \mathrm{l}$ to $\mu \mathrm{g} / \mathrm{l}$ levels in environmental samples (influents and effluents, surface water). Due to their highly potent mechanism of action (they directly or indirectly act with structure and function 
of DNA) these specific groups of drugs are conceived to be hazardous to living organisms and human health. There is a need to target them with environmental significance, quantify them, and assess their cytotoxic and genotoxic risk to living organisms [Scheurer et al. 2009, Kosjek and Heath 2011, Besse et al. 2012, Quinn et al. 2013, Zhang et al. 2013, Yu-Chen Lin et al. 2014].

In case of cytotoxicity and genotoxicity assessment bioassays are valuable bacterial assays based on genetically modified bacteria carrying a SOSregulon, DNA damage-inducible recA promoter upstream of enhanced-mutant variant of $g f p$ gene that is expressed when DNA repair is induced by chemical agents. So far, several constructs were tested, the SOS- $g f p$ biosensor with $r e c A$ promoter was found to be highly sensitive to the detection of carcinogens, cyto- and genotoxins. In such living cell systems, bacteria are especially attractive due to their rapid growth rate, low cost, and easy handling [Ptitsyn et al., 1997, Kostrzyńska et al. 2002, Zaslaver et al. 2004, Matejczyk 2010, Alhandrami and Paton 2013, Park et al. 2013].

The aim of the present study was to evaluate the potential applications of SOS- $g f p$ biosensor for in vitro rapid screening of cytotoxic and genotoxic effect of residues of anticancer and antidiabetic pharmacist in water. In experiment reporter strains of Escherichia coli $\mathrm{K}-12$ recA::gfpmut2 with a plasmid-borne transcriptional fusion between DNA-damage, genotoxin inducible rec $A$ promoter involved in the SOS regulon response and fast folding GFP variant reporter gene-gfpmut 2 was used.

In the presented data more stable and fast folding mutant of $g f p$ gene $-g f p m u t 2$ with excitation and emission wavelengths of 485 and $507 \mathrm{~nm}$ was used [Zaslaver et al. 2004].

\section{MATERIALS AND METHODS}

Bacteria strain and plasmid. In the experiment genetically modified Escherichia coli $\mathrm{K}-12$ MG1655 logarythmic phase cells: Escherichia coli K-12 recA::gfpmut2 and Escherichia coli $\mathrm{K}-12$ promoterless::gfpmut 2 were used (a gift from Prof. Uri Alon, Department of Molecular Cell Biology \& Department of Physics of Complex Systems, Weizmann Institute of Science Rehovot, Israel). They contained a pUA66 plasmid-borne transcriptional fusion between DNA-damage, genotoxinsensitive recA promoter involved in the SOS regulon response and fast folding GFP variant reporter gene-gfpmut2 [Zaslaver et al. 2004].
Bacteria growth condition. Escherichia coli K-12 MG1655 strains: Escherichia coli K-12 recA::gfpmut2 and Escherichia coli $\mathrm{K}-12$ promoterless::gfpmut 2 were cultured overnight in LB agar medium (Merck, Germany) at $30^{\circ} \mathrm{C}$ supplemented with $100 \mu \mathrm{g} / \mathrm{ml}$ of kanamycin (SigmaAldrich, Germany). Colonies were carried to LB broth medium $(10 \mathrm{~g} \mathrm{NaCl}, 10 \mathrm{~g}$ tryptone and $5 \mathrm{~g}$ yeast extract per $1000 \mathrm{ml}$ of distilled water) with $100 \mu \mathrm{g} / \mathrm{ml}$ of kanamycin and incubated overnight at $30{ }^{\circ} \mathrm{C}$. After that, bacteria cultures were refreshed in LB broth medium with $100 \mu \mathrm{g} / \mathrm{ml}$ of kanamycin and were cultivated to logarithmic phase of growth (2 hour cultivation). Following that, the cells were washed with PBS buffer (1.44 $\mathrm{g} \mathrm{Na}_{2} \mathrm{HPO}_{4}, 0.24 \mathrm{~g} \mathrm{KH}_{2} \mathrm{PO}_{4}, 0.2 \mathrm{~g} \mathrm{KCl}, 8 \mathrm{~g} \mathrm{NaCl}$ per $1000 \mathrm{ml}$ of destilled water, $\mathrm{pH}=7$ ).

Monitoring of bacteria growth and bacteria concentration. At the start of the experiment the initial bacteria cells density was standardized to $\mathrm{OD}=0.2$ (Optical Density) value by the use of spectrophotometer (Perkin Elmer Enspire 2300) at wavelength of $600 \mathrm{~nm}$. The concentration of bacteria cells per $\mathrm{ml}$ of PBS was assessed by series dilutions system and expressed as Colony Forming Units per $\mathrm{ml}(\mathrm{CFU} / \mathrm{ml})$ values. The growth dynamic of bacteria strains treated with CP (Sigma Aldrich, USA Company) and metformin (Bialystok pharmacy) was monitored with the use of standard spectrophotometer analysis of Optical Density values at wavelength of $600 \mathrm{~nm}$. The values of bacteria growth inhibition (GI) during the treatment with drugs at the start of bacteria incubation with drugs - time 0 and after 3 and 24 hours were calculated according to the formula: $\mathrm{GI}(\%)=\mathrm{OD}_{\mathrm{CS}}(\%)$ $-\mathrm{OD}_{\mathrm{DS}}(\%)$, Where: $\mathrm{OD}_{\mathrm{CS}}(\%)-$ Optical Density of control sample $=100 \%, \mathrm{OD}_{\mathrm{DS}}(\%)$ - Optical Density of bacteria samples treated with drugs.

Bacteria cells treatment with cyclophosphamide and metformin: $1 \mathrm{ml}$ of stationary phase bacteria cells $\left(1 \times 10^{8} \mathrm{CFU} / \mathrm{ml}\right.$; OD $\left.=0.2\right)$ were suspended in $4 \mathrm{ml}$ of PBS buffer and the following drugs were used in testing: cyclophosphamide $(\mathrm{CP})$, metformin $(\mathrm{M})$ and $\mathrm{CP}+$ metformin $(\mathrm{CP}+\mathrm{M})$ in five different concentrations, for CP: 0,0001 ; $0.001 ; 0.01 ; 0.1$ and $1 \mathrm{mg} / \mathrm{ml}$; for metformin: 0.3 ; 0.7 and $1 \mathrm{mg} / \mathrm{ml}$. For $\mathrm{CP}+$ metformin three different combinations were used: (1) $0.0001+0.3$; $0.001+0.3 ; 0.01+0.3 ; 0.1+0.3$ and $1+0.3 \mathrm{mg} / \mathrm{ml}$; (2) $0.001+0.7 ; 0.001+0.7 ; 0.01+0.7 ; 0,1+0,7$ and $1+0.7 \mathrm{mg} / \mathrm{ml}$ and (3) $0.001+1 ; 0.001+1 ; 0.01+1$; $0,1+1$ and $1+1 \mathrm{mg} / \mathrm{ml}$. Bacteria strains were incu- 
bated with drugs in 3 and 24 hours at $30^{\circ} \mathrm{C}$. Drugs concentrations were selected experimentally and after reviewing the reference recommendation [Rhizos and Elisaf 2013]. The time of bacteria incubation with drugs ( $3 \mathrm{~h}$ and $24 \mathrm{~h}$ ) was estimated for monitoring the sensitivity of recA::gfp genetic construct for quickly $(3 \mathrm{~h})$ and later $(24 \mathrm{~h})$ response. The control sample - Escherichia coli K-12 recA::gfpmut2 strain in PBS buffer was not treated with drugs. To verify the correct activity of recA promoter, Escherichia coli K-12 strain containing pUA66 plasmid without promoter Escherichia coli K-12 promoterless::gfpmut2 was used as a control. Additionally, to assess genotoxic sensitivity of recA::gfpmut2 construct, $4 \%$ acetone was used as a negative control and $50 \mu \mathrm{M}$ methylnitronitrosoguanidine (MNNG, known genotoxin) as positive control [Ptitsyn et. al. 1997, Kostrzyńska et. al. 2002].

Bacteria cells treatment with cyclophosphamide and metformin in surface water. Surface water samples were collected in sterile flasks from Białka river. Samples were sterilized by filtration. $1 \mathrm{ml}$ of logarythmic phase bacteria cells $\left(2 \times 10^{8} \mathrm{CFU} / \mathrm{ml} ; \mathrm{OD}=0.2\right)$ was suspended in $4 \mathrm{ml}$ of surface water at combination of CP $(0.1 \mathrm{mg} /$ $\mathrm{ml})$ and metformin $(1 \mathrm{mg} / \mathrm{ml})$ used in genotoxicity testing. Drug concentrations were selected to the highest stimulation of $g f p$ gene expression in PBS buffer (for IF=10.42). The conditions of bacteria incubations and the control protocols were the same as above.

Analytical method for the intensity of $g f p$ gene fluorescence (FI) analysis. After exposition of bacteria cultures to tested drugs strains were washed with PBS buffer and the intensity of fluorescence of $g f p$ gene in the volume of 1 $\mathrm{ml}$ of bacteria cells suspension $\left(1 \times 10^{4} \mathrm{CFU} / \mathrm{ml}\right)$ in PBS buffer was measured with spectrofluorometer (Perkin Elmer Enspire 2300). The measurements were taken at excitation and emission wavelengths of 485 and $507 \mathrm{~nm}$.

Assessment of SFI values. The specific fluorescence intensity (SFI) value which is defined as the fluorescence intensity (FI) divided by the optical density (OD) measured at each time point at $600 \mathrm{~nm}$ was calculated according to the following formula to detect the level of genotoxic activity of drugs: $S F I=\frac{F I}{O D}$, where: $S F I-$ Specific Fluorescence Intensity, $F I$ - the Fluorescence Intensity of the strains at excitation and emission wavelengths of 485 and $507 \mathrm{~nm}, O D$ - Optical Density at 600 $\mathrm{nm}$ of the strains.

Detection of $\mathbf{S}_{\text {gfpexp. }}$ and $\mathbf{I}_{\text {gfpexp. }}$ values. For each concentration of the tested drugs the levels of stimulation of $g f p\left(\mathrm{~S}_{g f p e x p}\right)$ or inhibition $\left(\mathrm{I}_{\text {gfpexp. }}\right)$ were calculated, according to the formulas:

- for the SFI values with an increase with the level of $g f p$ expression (CP and $\mathrm{CP}+$ metformin) in comparison with the control sample: $\mathrm{S}$ $(\%)=\operatorname{SFI}_{\mathrm{DS}}(\%)-\mathrm{SFI}_{\mathrm{CS}}(\%)$, where $\mathrm{SFI}_{\mathrm{DS}}(\%)$ - SFI values for tested drugs sample, $\mathrm{SFI}_{\mathrm{CS}}$ $(\%)$ - SFI for control sample, $=100 \%$,

- for the SFI values with a decrease with the level of $g f p$ expression (metformin) in comparison to the control sample: $\mathrm{I}_{g \text { fpexp. }}(\%)=\mathrm{SF}-$ $\mathrm{I}_{\mathrm{CS}}(\%)-\mathrm{SFI}_{\mathrm{DS}}(\%), \mathrm{SFI}_{\mathrm{CS}}(\%)-\mathrm{SFI}$ for control sample, $=100 \%, \mathrm{SFI}_{\mathrm{DS}}(\%)-\mathrm{SFI}$ values for tested drugs sample.

Assessment of $F_{I}$ values. For each concentration of the tested drugs induction factors $\left(\mathrm{F}_{\mathrm{I}}\right)$ were calculated. $\mathrm{F}_{\mathrm{I}=}\left(\mathrm{FI}_{\mathrm{I}} / \mathrm{OD}_{0}\right) /\left(\mathrm{Fl}_{0} / \mathrm{OD}_{\mathrm{I}}\right)$, where $\mathrm{FI}_{\mathrm{I}}$ is the fluorescence intensity of the culture treated with DNA - damaging compound; $\mathrm{Fl}_{0}$ is the fluorescence intensity of the control sample without genotoxin; $\mathrm{OD}_{\mathrm{I}}$ is the optical density at $600 \mathrm{~nm}$ of treated culture and $\mathrm{OD}_{0}$ is the optical density of the control sample. The $\mathrm{F}_{\mathrm{I},} \mathrm{S}_{\text {gfpexp }}$ and $\mathrm{I}_{\text {gfpexp. }}$ values express the potency of genotoxic activity of both drugs.

Classification of tested drugs as genotoxins. The $F_{I}$ values were calculated for classification of the tested drugs as genotoxins. According to Ptitsyn et. al. [1997] and Kostrzyńska et. al. [2002], genotoxin was identified as a chemical if its induction factor was 2 or more $\left(\mathrm{F}_{1} \geq 2\right)$.

Statistical analysis. Experiments were conducted in three independent series. Statistical data obtained in this study are expressed as mean \pm standard deviation (SD) for $n=6$. The data were analyzed with the use of standard statistical analyses, including one-way Student's test for multiple comparisons to determine the significance between different groups. The values of $P<0.05$ were considered as significant.

\section{RESULTS}

Logarithmic phase Escherichia coli K-12 MG1655 recA::gfpmut2 strain treatment with cyclophosphamide (CP) and metformin (M) showed that separate administration of both drugs caused 
a significant dose- and time-dependent decreased $(P<0.05)$ in SFI value and increased the inhibition of $r e c A$ promoter activity and intensified $\mathrm{I}_{\text {gfpexp. }}$. value compared to non-treated cells in PBS buffer (control sample) (Table 1). A sustained decrease in SFI values was observed after 24 hours incubation of bacteria cells with both drugs.

$3 \mathrm{~h}$ and $24 \mathrm{~h}$ simultaneous co-administration of $\mathrm{CP}+\mathrm{M}$ to a logarithmic phase the bacteria (especially up to $24 \mathrm{~h}$ ) significantly modulated $\mathrm{CP}$ activity and intensified the sensitivity of $\mathrm{rec} A$ promoter and $g f p$ gene expression and stimulated SFI, $F_{I}\left(F_{I} \geq 2\right)$ and $S_{\text {gfpexp. }}$ values compared to control sample and samples treated separately with $\mathrm{CP}$ and $\mathrm{M}$. Progressive significant stimulation of $\mathrm{SFI}, \mathrm{F}_{\mathrm{I}}$ and $\mathrm{S}_{\text {gfpexp. }}$ values were obtained for higher concentration of CP $(1 ; 0.1 ; 0.01 ; 0.001 \mathrm{mg} / \mathrm{ml})$ and $\mathrm{M}(1 ; 0.7 \mathrm{mg} / \mathrm{ml})$ during $3 \mathrm{~h}$ and $24 \mathrm{~h}$ incubation comparing to control sample. The maximum point for $r e c A$ promoter stimulation was observed for co-adminiastration of $0.1 \mathrm{mg} / \mathrm{ml} \mathrm{CP}$ and $1 \mathrm{mg} /$ $\mathrm{ml} \mathrm{M}$ in $24 \mathrm{~h}\left(\mathrm{~S}_{\text {gfpexp. }}=838 \%\right)$.

Table 1. SFI values for logarithmic phase E. coli K-12 recA::gfp mut2 treated with cyclophosphamide (CP), metformin $(\mathrm{M})$ and combination of $\mathrm{CP}$ and metformin $(\mathrm{CP}+\mathrm{M})$ in three different metformin concentrations $(0.3 ; 0.7$; $1 \mathrm{mg} / \mathrm{ml}$ ) in comparison with the control sample (bacteria strain in PBS buffer)

\begin{tabular}{|c|c|c|c|c|c|c|c|c|c|c|}
\hline $\begin{array}{c}\mathrm{CP} \\
(\mathrm{mg} / \mathrm{ml})\end{array}$ & $\begin{array}{c}\mathrm{M} \\
(\mathrm{mg} / \mathrm{ml})\end{array}$ & $\mathrm{t}$ & $\begin{array}{c}\text { Control sample } \\
\text { SFI } \pm S D\end{array}$ & $\begin{array}{c}M \\
S F I \pm S D\end{array}$ & $\begin{array}{l}\mathrm{I}_{\text {gffexp }} \\
(\%)\end{array}$ & $\begin{array}{c}\mathrm{CP} \\
\mathrm{SFI} \pm \mathrm{SD}\end{array}$ & $I_{g f p \exp }(\%)$ & $\begin{array}{c}\mathrm{CP}+\mathrm{M} \\
\mathrm{SFI} \pm \mathrm{SD}\end{array}$ & $\mathrm{F}_{1}$ & $\begin{array}{l}S_{\text {gfpexp. }} \\
(\%)\end{array}$ \\
\hline \multirow{6}{*}{1} & \multirow[t]{2}{*}{0.3} & 3 & $18.45 \pm 3.43$ & $15.54 \pm 2.84^{*}$ & 15.8 & $16.23 \pm 2.3^{* *}$ & 12 & $22.30 \pm 2.45^{* b c}$ & - & - \\
\hline & & 24 & $38.90 \pm 6.56$ & $31.12 \pm 4.20^{\mathrm{a}}$ & 20 & $19.34 \pm 2.73^{\mathrm{ab}}$ & 50 & $103 \pm 8.20^{\mathrm{abc}}$ & 2.65 & 165 \\
\hline & \multirow[t]{2}{*}{0.7} & 3 & $18.45 \pm 3.43$ & $14.14 \pm 3.84^{*}$ & 15.8 & $16.23 \pm 2.3^{* *}$ & 12 & $41.0 \pm 4.40^{\mathrm{abc}}$ & 2.22 & 122 \\
\hline & & 24 & $38.90 \pm 6.56$ & $27.65 \pm 4.43^{a}$ & 20 & $19.34 \pm 2.73^{\mathrm{ab}}$ & 50 & $163 \pm 8.23^{\mathrm{abc}}$ & 4.20 & 320 \\
\hline & \multirow[t]{2}{*}{1} & 3 & $18.45 \pm 3.43$ & $13.70 \pm 2.03^{*}$ & 15.8 & $16.23 \pm 2.3^{\text {tb }}$ & 12 & $89 \pm 6.40^{\mathrm{abc}}$ & 4.82 & 382 \\
\hline & & 24 & $38.90 \pm 6.56$ & $25.30 \pm 3.43^{a}$ & 20 & $19.34 \pm 2.73^{\mathrm{ab}}$ & 50 & $270 \pm 10.75^{\mathrm{abc}}$ & 6.94 & 594 \\
\hline \multirow{6}{*}{0.1} & \multirow[t]{2}{*}{0.3} & 3 & $18.45 \pm 3.43$ & $15.54 \pm 2.84^{*}$ & 15.8 & $17.14 \pm 2.22^{* *}$ & 7 & $21.14 \pm 2.54^{* b^{*}}$ & - & - \\
\hline & & 24 & $38.90 \pm 6.56$ & $31.12 \pm 4.20^{\mathrm{a}}$ & 20 & $21.14 \pm 2.73^{a b}$ & 55.66 & $130 \pm 8.43^{\mathrm{abc}}$ & 3.34 & 134 \\
\hline & \multirow[t]{2}{*}{0.7} & 3 & $18.45 \pm 3.43$ & $14.14 \pm 3.84^{*}$ & 15.8 & $17.14 \pm 2.22^{* *}$ & 7 & $38 \pm 3.10^{\mathrm{abc}}$ & 2.06 & 106 \\
\hline & & 24 & $38.90 \pm 6.56$ & $27.65 \pm 4.43^{a}$ & 20 & $21.14 \pm 2.73^{\mathrm{ab}}$ & 55.66 & $240 \pm 9.20^{\mathrm{abc}}$ & 6.17 & 517 \\
\hline & \multirow[t]{2}{*}{1} & 3 & $18.45 \pm 3.43$ & $13.70 \pm 2.03^{*}$ & 15.8 & $17.14 \pm 2.22^{* b}$ & 7 & $150 \pm 7.20^{\mathrm{abc}}$ & 8.13 & 713 \\
\hline & & 24 & $38.90 \pm 6.56$ & $25.30 \pm 3.43^{a}$ & 20 & $21.14 \pm 2.73^{\mathrm{a}^{*}}$ & 55.66 & $365 \pm 11.30^{\mathrm{abc}}$ & 9.38 & 838 \\
\hline \multirow{6}{*}{0.01} & \multirow[t]{2}{*}{0.3} & 3 & $18.45 \pm 3.43$ & $15.54 \pm 2.84^{*}$ & 15.8 & $17.93 \pm 1.92^{* *}$ & 2.8 & $20.12 \pm 1.13^{* b^{*}}$ & - & - \\
\hline & & 24 & $38.90 \pm 6.56$ & $31.12 \pm 4.20^{\mathrm{a}}$ & 20 & $22.30 \pm 2.45^{\mathrm{ab}}$ & 42.67 & $98 \pm 5.45^{\mathrm{abc}}$ & 2.52 & 152 \\
\hline & \multirow[t]{2}{*}{0.7} & 3 & $18.45 \pm 3.43$ & $14.14 \pm 3.84^{*}$ & 15.8 & $17.93 \pm 1.92^{* b}$ & 2.8 & $32 \pm 2.22^{\mathrm{abc}}$ & - & - \\
\hline & & 24 & $38.90 \pm 6.56$ & $27.65 \pm 4.43^{\mathrm{a}}$ & 20 & $22.30 \pm 2.45^{\mathrm{ab}}$ & 42.67 & $160 \pm 7.24^{\mathrm{abc}}$ & 4.11 & 311 \\
\hline & \multirow[t]{2}{*}{1} & 3 & $18.45 \pm 3.43$ & $13.70 \pm 2.03^{*}$ & 15.8 & $17.93 \pm 1.92^{* b}$ & 2.8 & $121 \pm 6.23^{\mathrm{abc}}$ & 6.56 & 556 \\
\hline & & 24 & $38.90 \pm 6.56$ & $25.30 \pm 3.43^{a}$ & 20 & $22.30 \pm 2.45^{\mathrm{a}^{*}}$ & 42.67 & $200 \pm 9.17^{\mathrm{abc}}$ & 5.14 & 414 \\
\hline \multirow{6}{*}{0.001} & \multirow[t]{2}{*}{0.3} & 3 & $18.45 \pm 3.43$ & $15.54 \pm 2.84^{*}$ & 15.8 & $18.02 \pm 2.43^{* *}$ & 2.33 & $24.22 \pm 2.46^{t} \mathrm{~b}^{*}$ & - & - \\
\hline & & 24 & $38.90 \pm 6.56$ & $31.12 \pm 4.20^{\mathrm{a}}$ & 20 & $29.34 \pm 2.93^{* *}$ & 24.58 & $120 \pm 6.56^{\mathrm{abc}}$ & 3.08 & 208 \\
\hline & \multirow[t]{2}{*}{0.7} & 3 & $18.45 \pm 3.43$ & $14.14 \pm 3.84^{*}$ & 15.8 & $18.02 \pm 2.43^{* b}$ & 2.33 & $36 \pm 3.74^{\mathrm{abc}}$ & - & - \\
\hline & & 24 & $38.90 \pm 6.56$ & $27.65 \pm 4.43^{\mathrm{a}}$ & 20 & $29.34 \pm 2.93^{\mathrm{a}^{*}}$ & 24.58 & $180 \pm 8.40^{\mathrm{abc}}$ & 4.63 & 363 \\
\hline & \multirow[t]{2}{*}{1} & 3 & $18.45 \pm 3.43$ & $13.70 \pm 2.03^{*}$ & 15.8 & $18.02 \pm 2.43^{* b}$ & 2.33 & $110 \pm 6.10^{\mathrm{abc}}$ & 5.96 & 496 \\
\hline & & 24 & $38.90 \pm 6.56$ & $25.30 \pm 3.43^{a}$ & 20 & $29.34 \pm 2.93^{\mathrm{ab}}$ & 24.58 & $130 \pm 7.23^{\mathrm{abc}}$ & 3.34 & 234 \\
\hline \multirow{6}{*}{0.0001} & \multirow[t]{2}{*}{0.3} & 3 & $18.45 \pm 3.43$ & $15.54 \pm 2.84^{*}$ & 15.8 & $18.28 \pm 2.87^{* b}$ & 0.9 & $20 \pm 1.76^{* b^{*}}$ & - & - \\
\hline & & 24 & $38.90 \pm 6.56$ & $31.12 \pm 4.20^{\mathrm{a}}$ & 20 & $37.34 \pm 3.83^{* b}$ & 4 & $40 \pm 4.84^{* b^{*}}$ & - & - \\
\hline & \multirow[t]{2}{*}{0.7} & 3 & $18.45 \pm 3.43$ & $14.14 \pm 3.84^{*}$ & 15.8 & $18.28 \pm 2.87^{* b}$ & 0.9 & $26 \pm 2.24^{* b^{*}}$ & - & - \\
\hline & & 24 & $38.90 \pm 6.56$ & $27.65 \pm 4.43^{\mathrm{a}}$ & 20 & $37.34 \pm 3.83^{* b}$ & 4 & $42 \pm 4.32^{* \mathrm{~b}^{*}}$ & - & - \\
\hline & \multirow[t]{2}{*}{ 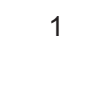 } & 3 & $18.45 \pm 3.43$ & $13.70 \pm 2.03^{*}$ & 15.8 & $18.28 \pm 2.87^{\star b}$ & 0.9 & $23.3 \pm 3.16^{* b^{*}}$ & - & - \\
\hline & & 24 & $38.90 \pm 6.56$ & $25.30 \pm 3.43^{a}$ & 20 & $37.34 \pm 3.83^{* b}$ & 4 & $48.30 \pm 5.03^{* b^{*}}$ & - & - \\
\hline
\end{tabular}

Comments: $\mathrm{T}$ - time of bacteria strain incubation with drugs, FI - induction factor values, Igfpexp. (\%) - the percent of inhibition of gfp expression after treatment of bacteria cells with M and CP in comparison with the control sample (100\%), Sgfpexp. (\%) - the percent of stimulation of gfp expression after treatment of bacteria cells with $\mathrm{CP}$ and $\mathrm{CP}+\mathrm{M}$ in comparison with the control sample $(100 \%)$. Data points represent mean values $\pm S D ; n=6$; a - significantly different from control $(p<0.05)$; $\mathrm{b}$ - significantly different from metformin $(\mathrm{M})$ group $(\mathrm{p}<0.05)$; $\mathrm{c}$ - significantly different from cyclophosphamide $(\mathrm{CP})$ group $(\mathrm{p}<0.05) ; *$ - no significantly different. 
In case of bacteria incubation bacteria incubation with $\mathrm{CP}$ and $\mathrm{M}$ administrated separately there was no increase in $F_{I}$ values $\left(F_{I} \geq 2\right)$ for two phases of bacteria cells. $\mathrm{F}_{\mathrm{I}}$ values $\geq 2$ were obtained for the highest concentration of $\mathrm{CP}$ and $\mathrm{M}$ in simultaneous co-administration of both drugs. The treatment of bacteria with the smallest concentration of CP $(0.0001 \mathrm{mg} / \mathrm{ml})$ resulted in a progressive decrease in $\mathrm{F}_{\mathrm{I}}$ (below 2) values.

The monitoring of bacteria cultures growth (OD) at the start of bacteria incubation (time 0) and after 3 and $24 \mathrm{~h}$ with drugs, indicated significant increase in GI (growth inhibition) values for all tested concentration of M and CP in $24 \mathrm{~h}$ treatment. Simultaneous action of both drugs on bacteria cells significantly enhanced the growth inhibition values in $24 \mathrm{~h}$ incubation in comparison to separate administration of the drugs and comparable to control sample. In shorter time $(3 \mathrm{~h})$ of drugs influence on bacteria cells, there were no statistically important differences for OD values.

Metformin, in relation to CP caused statistically significant increase in the cytotoxic and genotoxic activity of CP. Logarithmic phase prolonged treatment (up to $24 \mathrm{~h}$ ) of bacteria cells with metformin at concentrations of 0.7 and 1 $\mathrm{mg} / \mathrm{ml}$ significantly influenced the growth inhibition of bacteria. After $3 \mathrm{~h}$ of incubation there were no significant changes in OD values. Bacteria incubated with PBS buffer (control sample) without any drug, resulted in no statistical differences in OD value from 0 to 24 hours of continuous cultivation.

The treatment of $g f p$ biosensor bacteria strain in surface water $(\mathrm{n}=6)$ enhanced the sensitivity of recA::gfpmut 2 genotoxic system and increased the stimulation of $g f p$ expression and SFI value in comparison to incubation in PBS buffer. Prolonged treatment (up to $24 \mathrm{~h}$ ) of bacteria cells with combination of CP $(0.1 \mathrm{mg} / \mathrm{ml})$ and metformin $(1 \mathrm{mg} / \mathrm{ml})$ in surface water significantly influenced $g f p$ expression with the maximum values of $\mathrm{IF}=13.20$ and $1220 \%$ of $\mathrm{S}_{\text {gfpexp }}$ values comparable to control sample.

\section{DISCUSSION}

Previous studies showed that recA promoter was induced by known genotoxins and selected anticancer drugs [Ptitsyn et al. 1997, Kostrzyńska et al. 2002, Zaslaver et al. 2004, Matejczyk 2010, Alhandrami and Paton 2013, Park et al. 2013]. According to the results obtained in our experi- ment $\mathrm{M}$ in simultaneous co-administration with $\mathrm{CP}$ was shown to modulate and dramatically increase the reactivity of $r e c A$ promoter in relation to separate bacteria treatment with $\mathrm{CP}$ and $\mathrm{M}$.

Amador et. al. [2012] indicated, that chronic metformin exposure may be potentially genotoxic in vitro. The results of the above experiment provided the confirmation of the possible influence of metformin on the genes, especially in quickly dividing cells, because in $50 \%$ of cases there were significant differences (comparable to the control sample) in the level of recA promoter sensitivity and $g f p$ expression after logarithmic phase bacteria treatment with the whole applied concentrations of metformin and in longer time of incubation (up to $24 \mathrm{~h}$ ).

Our results indicated that prolonged exposure of bacteria to metformin (up to $24 \mathrm{~h}$ ) in coadministration with $\mathrm{CP}$ resulted in a progressive stimulation of $r e c A$ promoter reactivity and $g f p$ gene expression. $\mathrm{F}_{\mathrm{I}}$ values $\geq 2$ were obtained for CIS+M after 24 hours and for $3 \mathrm{~h}$ of incubation. The strongest stimulation of recA promoter and $g f p$ expression was noticed after addition of the higher CP concentration - 1, 0.1 and $0.01 \mathrm{mg} /$ $\mathrm{ml}$ than for lower concentrations of antidiabetic drug. The investigated concentrations of $M$ and $\mathrm{CP}$ inhibited SFI values of bacteria growth in the logarithmic phase. It can be suggested the possible repression of recA::gfp genetic construct on transcription by both drugs. Our results showed that CP treatment significantly inhibited E. coli $\mathrm{K}-12$ longer (up to $24 \mathrm{~h}$ ) bacteria cells growth. Metformin could has cytotoxic effect by inhibition of bacteria cells growth, for highest applied concentrations and $24 \mathrm{~h}$ treatment. CP is a very active drug, especially for dividing cells. The above data confirmed that coadministration of $\mathrm{CP}+\mathrm{M}$ importantly intensified cytotoxic effect and recA promoter activity. The obtained results are in agreement with earlier empirical studies of other authors (with the use of cisplatin) who demonstrated that co-administration of metformin with chemotherapeutic agents intensified the inhibition of cancer cells proliferation and significantly improved cisplatin-induced cytotoxicity [Quinn et al. 2013]. DNA damage can initiate a cascade of cellular biological effects including cell death. The direct and indirect metformin influence on DNA could be the main biological mechanism of enhancement the cytotoxic and genotoxic activity of CP, especially in simultaneous co-administration of both drugs. 
Preliminary results indicated stronger reactivity of recA::gfpmut2 genetic system in surface water for drugs treated samples $(n=6)$ (data not shown). The influence of surface water on genetic system, which was used, could be a consequence of the presence of different chemicals (e.g. compounds from hospitals) in surface water than we used in our experiment. These unknown water compounds could increase the $g f p$ expression in bacteria strain, similarly to the drugs (cyclophosphamide and metformin) used in our experiments. The maximum point for $r e c A$ promoter stimulation was observed for co-adminiastration of $0,1 \mathrm{mg} / \mathrm{ml}$ $\mathrm{CP}$ and $1 \mathrm{mg} / \mathrm{ml} \mathrm{M}$ in $24 \mathrm{~h}$ being $\mathrm{S}_{\text {gfpexp. }}=1220 \%$ (as compared to $\mathrm{S}_{\text {gfpexp. }}=838 \%$ for $\mathrm{CP}$ and $\mathrm{M}$ in PBS).

To assess genotoxic sensitivity of $r e c A:: g f p$ genetic biosensing system $4 \%$ acetone was tested as a negative control. For this chemical $\mathrm{F}_{\mathrm{I}}$ values did not increase during $3 \mathrm{~h}$ and $24 \mathrm{~h}$ of incubation. Methylnitronitrosoguanidine (MNNG) at concentration of $50 \mu \mathrm{M}$ was used as a positive control. For this chemical $\mathrm{F}_{\mathrm{I}}=8.4$ during $24 \mathrm{~h}$ incubation and $\mathrm{F}_{\mathrm{I}}=2.8$ during $3 \mathrm{~h}$ were obtained (data not shown). These results showed stronger sensitivity of $\operatorname{rec} A: \because g f p$ biosensing system for MNNG than acetone stressor.

\section{CONCLUSIONS}

1. The results of the presented study indicated that recA::gfpmut 2 genetic system was sensitive to drugs applied in experiment and drugs mixture.

2. RecA promoter was a good bioindicator for cytotoxic and genotoxic effect screening of cyclophosphamide, metformin and the mixture of the both drugs in PBS buffer and surface water.

3. The results indicated that E. coli $\mathrm{K}-12$ recA::gfp mut2 strain could be potentially useful for first-step screening of cytotoxic and genotoxic effect of anticancer and antidiabetic pharmacist residues in water.

4. Next steps in research will include more experimental analysis to validate recA::gfpmut2 genetic system in $E$. coli $\mathrm{K}-12$ on different anticancer drugs.

\section{Acknowledgements}

Authors are very grateful to Prof. Uri Alon, Department of Molecular Cell Biology \& Department of Physics of Complex Systems, Weizmann Institute of Science Rehovot, Israel for providing bacteria strains. This work was financially supported by research project number S/WBiIŚ/3/2011.

\section{REFERENCES}

1. Besse J.P., Latour J.-F., Garric J. 2012. Anticancer drugs in surface waters. What can we say about the occurrence and environmental significance of cytotoxic, cytostatic and endocrine therapy drugs? Environ. Intern., 39, 73-86.

2. Zhang J., Chang V.W.C., Giannis A., Wang A.-Y. 2013. Removal of cytostatic drugs from aquatic environment: A review., Scien. Tot. Environ., 445446, 281-298.

3. Yu-Chen Lin A., Lin Y.C., Lee W.N. 2014. Prevalence and sunlight photolysis of controlled and chemotherapeutic drugs in aqueous environments. Environm. Poll., 187, 170-181.

4. Kosjek T., Heath E. 2011. Occurrence, fate and determination of cytostatic pharmaceuticals in the environment, Tr. AC. Trends Anal. Chem., 30, 1065-1087.

5. Quinn B.J., Kitagawa H., Memmott R.M., Gills J.J., Dennis P.A. 2013. Repositioning metformin for cancer prevention and treatment, Trends. Endocrinol. Metabol., 24, 9, 469-480.

6. Scheurer M., Sacher F., Brauch H.J. 2009. Occurrence of the antidiabetic drug metformin in sewage and surface waters in Germany, J Environ. Monit., $11,9,1608-1613$.

7. Kostrzyńska M, Leung K.T., Lee H., Trevors J.T. 2002. Green fluorescence protein based biosensor for detecting SOS-inducing activity of genotoxic compounds. J Microbiol. Meth., 48, 43-51.

8. Matejczyk M. 2010. The Potency of application of microbial biosensors. Advances in Microbiology (In Polish). 49, 4, 297-304.

9. Alhadrami H.A., Paton G.I. 2013. The potential applications of SOS-lux biosensors for rapid screening of mutagenic chemicals. FEMS Microbiol. Lett., 344, 1, 69-76.

10. Park M., Tsai S.L., Chen W. 2013. Microbial Biosensors: Engineered microorganisms as the sensing machinery. Sensors, 13, 5777-5795.

11. Zaslaver A., Mayo A.E., Rosemberg R., Bashkin P., Sberro H., Tsalyuk M., Surette M.G., Alon U. 2004. Just-in-time transcription program in metabolic pathways. Nat. Genet., 36, 5, 486-491.

12. Ptitsyn L.R., Horneck G., Komova O., Kozubek S., Krasavin E.A., Bonev M., Rettberg P. 1997. A biosensor for environmental genotoxin screening based on an SOSlux assay in recombinant Escherichia coli cells. Appl. Environm. Microbiol., 63, 4377-4384.

13. Amador R.R., Longo J.P.F., Lacava Z.G., Dorea J.G. 2012. Almeida Santos M. de F.M. Metformin (dimethyl-biquanide) induced DNA damage in mammalian cells. Gen. Mol. Biol., 35, 1, 153-158. 